as a prophylactic measure and from the fact that we can never be certain, however well excision has been performed, that all the diseased tissue has been completely removed. I have always found a reaction from the tuberculin injections after apparent thorough extirpation of very small patches of lupus, showing, I think, definitely, some remaining tuberculous material somewhere.

I am, Sirs, yours faithfully,

Newport, Mon., Nov. 28th, 1903

C. STANSER BowKeR.

\section{THE BEHAVIOUR OF CANCER IN NERVE AREAS.}

To the Editors of THE LANCET.

SIRs, - May I be allowed to add two remarks which your reporter omitted in epitomising my communication to the meeting of the Pathological Society of London held on Nov. 17th. I was speaking on the behaviour of carcinoma within nerve or trophic areas. I showed rodent ulcers corresponding to the areas of distribution of certain muscles. Your reporter omitted to say that they were the cutaneous muscles of the face. The addition is an important one because it is as yet unknown what is the exact nervous relationship between those cutaneous muscles and the skin of which they are component parts.

Neither does the epitome include that $I$ showed, or attempted to show, that muscular, fascial, vascular, and lymphatic limitations were not the predominent factors of distribution of these ulcers, but their spread and areas of occupation were probably mainly influenced by a nerve or trophic agency. I am, Sirs, yours faithfully,

Harley-street, W., Nov. 25th, 1903. G. LenTHAL ChEATLE.

\section{MEDICAL FACULTY OF THE UNIVERSITY OF LIVERPOOL.}

\section{To the Editors of THE LANCET.}

Sins, - My attention has been drawn to a mistake in the return made by me of the winter entry of medical students at the University of Liverpool and published in THE LANCET of Oct. 31st (p. 1242). The number 111 in the first column represents the total number of students now in the school who are taking the full medical curriculum. The number of students entering for the first time and taking the full medical course is 23 , as against 24 last year.

$$
\text { I am, Sirs, yours faithfully, }
$$

$$
\text { B. MOORE, }
$$

Dec. 1st, 190 . Dean of Medical Faculty.

\section{SHIPS' SURGEONS AND FEES FROM PASSENGERS. \\ To the Editors of THE LANCET.}

SIRs, - In a series of articles on "Life on a Liner" pub. lished recently in Lloyd's Weekly I notice that "The Ship's Doctor" refers to the subject of fees from passengers for medical attendance. His remarks are as follows :-

Many travellers are in doubt as to the position of the sinip's doctor in regard to his remuneration from passengers for services rendered. The Merchant Shipping Act enacts that "every foreign-going ship having 100 persons on board, or upwards, shall carry on board as part of her complement a duly qualified medical practitioner." Furthermore, an emigrant ship (i.e., a foreign-going ship which carries 50 or more steerage passengers) must have a medical man irrespective of the number of the crew or of the otber passengers carried. The salary of the doctor on board is commensurate with these duties to his ship. To any passengers who are suffering from ordinary forms of sea-sickness and its concomitant evils or who receive injuries which are in any way due to the ship-for example, as from a fall produced by the ship's rolling-the doctor's services are free. For any sickness contracted before sailing or during a voyage which is not connected whe the above-named conditions he is enetitl hich to a remuneration at the same rate as hew expect that his services to passengers should be rendered gratis as it would be for any visitor in a hotel or traveller on the rallway to expect to have medical attendance free in any illness for which the hotel or railway authorities could not be held responsible.

The case has here been put clearly and concisely. After seven years' experience in first-class ocean-going steamers I should like to supplement these remarks with a few of my own observations. Ships' surgeons are of two kinds: 1 . Those who at the end of a college curriculum, for health or the sake of pleasure and to see the world, take a voyage or two as surgeon thereby saving travelling expenses. Such men, I take it, are not particularly interested in the emoluments attached to any position which they do not intend to hold for any time. Not a few, I fear, have earned a reputation for intemperate habits, hence the suspicion still lurks in the minds of too many that because a man is a ship's surgeon therefore he is not much good. 2. 'Those who for various reasons elect to make the sea life a permanency. That the post of ship's surgeon in first-class passenger lines is difficult to obtain and that attainments, professional and social, of a high order are required of those who hold them are known best to those concerned. "The Ship's Doctor," in quoting from the Merchant Shipping Act, demonstrates clearly that in large passenger ships the surgeon's first obligations are to his ship and the crew for whose benefit he is employed by the company. For this he receives a "wage" varying from $£ 6$ to a maximum of $£ 10$ per month. Were this to be the only remuneration obtainable at sea it is reasonable to suppose that no experienced or well-qualified surgeon could stay any time on a ship.

As regards passengers in relation to the surgeon I think the following groups will include all: (1) the passenger who takes the initiative by remunerating the surgeon, perhaps handsomely, for any services rendered; (2) the passenger who, at the end of a consultation or attendance, will at once ask for his bill and pay it if reasoriable; $(3)$ the passenger who, travelling perhaps for the first time, really does not know whether to approach the surgeon or to wait for a bill being sent in or what he ought to do but is pleased to be enlightened on the matter; (4) the passenger who, either wilfully or through ignorance, clings to the old-time notion that the surgeon is there solely for the benefit of passengers ; and (5) the passenger who never intends to pay the surgeon any more than he intends to tip the steward or the stewardess for any services rendered.

Of these groups the last two are obviously unsatisfactory to deal with. The difficulty is increased by the fact that seldom is a ship's surgeon allowed by his company to send in a regular bill for attendance as he could do on shore. Why he should not do so and thereby make it a matter of ordinary business instead of sentiment seems difficult to imagine. I presume that the particulars of the bill would be open to analysis both by the patient and by the company if referred to them; therefore any overcharge by the ship's surgeon who did not kncw his business could be remedied or repudiated. I have met at least three managers who have considered it right and proper that the surgeon should send in a bill for attendance. Of these one I remember who summoned me to answer the charge made by a passenger that I had presented him with a bill for five guineas for three weeks' attendance while suffering from syphilitic ulceration of the mouth. "Doctor," said the manager, "I am surprised at your folly for trying to convert our ship into a hospital for the treatment of venereal disease. Tou ought to have charged that man 25 instead of five guineas." In "Presbrey's Information Guide for Transatlantic Travellers," published and circulated on all steamers by the Frank Presbrey Company, New York, U.S.A., the following lines appear : 'It is an erroneous impression that the ship's physician is provided solely for the accommodation of passengers. Maritime laws require steamship companies to employ physicians on all vessels carrying large crews. Every transatlantic steamer carries a competent physician and surgeon whose services are obtainable by passengers at corresponding rates of remuneration to those paid on shore." This recommendation from such a reputable source is valuable, but, of course, is not "official." Even if companies were to allow their surgeons to send in a bill I know from experience and for reasons already stated that in the majority of cases there would be no occasion to render it. In order to deal with the class of passengers who do not intend to pay the surgeon at all, the remedy 1 would suggest is that the bill be sent in not in the surgeon's, but in the company's, name. This would bring home the obligation to the passenger and the company could deal thereafter with the surgeon on the matter as they considered proper. "The Ship's Doctor" is wise in recognising that no remuneration should be suggested in the case of an injury to a passenger being due to any fault of the ship or carelessness, perhaps, of the crew.

One other point. Passengers often call at, or send to, the surgery for pills, powders, \&c., where no attendance or consultation is asked or even necessary. I have known ships' surgeons foolish enough to make a charge for these. This is radically wrong, inasmuch as the drugs 